\title{
Down Sendromlu Hastalarda Tiroid Disfonksiyonu; Klinik ve Kromozom Korelasyonu
}

\section{Thyroid Dysfunction in Down syndrome Patients; Clinical and Chromosomal Correlation}

\author{
${ }^{1}$ Rana Mumtaz MATLOB, ${ }^{2}$ Mayada Ilias YALDA, ${ }^{3}$ Dian Jamel SALIH, ${ }^{4}$ Dina Qais FARAJ \\ ${ }^{1}$ M.B.Ch.B, MSc. Embryology, Assistant Lecturer; university of Duhok, college of medicine, Duhok, Iraq \\ ${ }^{2}$ M.B.Ch.B, M.Sc. Ph.D. Pathology; Associate Professor; university of Duhok, college of medicine, Duhok, Iraq \\ ${ }^{3}$ M.Sc. Cytogenetics, Lecturer, university of Duhok, college of medicine, Duhok, Iraq \\ ${ }^{4}$ BSc Pharmacy, University of Duhok, College of Pharmacy Duhok, Iraq
}

\author{
Dian Salih: https: //orcid.org/0000-0003-1006-086X \\ Rana Matlob: https: //orcid.org/0000-0002-0933-8724 \\ Mayada Yalda: https: //orcid.org/0000-0003-2778-9147 \\ Tamara Faraj: https: //orcid.org/0000-0002-2831-0778
}

\section{ÖZ}

Amaç: Otoimmün hastalıkların Down sendromlu kişilerde, özellikle hipotiroidizmde meydana geldiği bilinmektedir. Bu çalışmanın temel amacı, Down sendromlu hastalarda anormal tiroid fonksiyonunun sıklığını tahmin etmek ve Irak, Duhok eyaletindeki yaş, kraniyofasiyal özellikler ve kromozomal anormalliklerin türü ile ilişkilerini değerlendirmektir.

Materyal ve Metot: Çalışmaya Down sendromlu 58 hasta dahil edilmiş; hepsi ana kraniyofasiyal özelliklerin varlığı açısından incelenmiştir. Tiroid fonksiyon testi ve kromozomal analiz için karyotipleme yapmak için olgulardan kan örnekleri alındı.

Bulgular: Down sendromlu 58 hastanın 25 'inde (\% 43.11) subklinik hipotiroidi vardı. Yaş grubu ile subklinik hipotiroidi yüzdesi arasında istatistiksel anlamlılık yoktu. En sık görülen kraniyofasiyal özellik, nispeten yüksek bir subklinik hipotiroidizm yüzdesine sahip epikantal kıvrımlar olmasına rağmen bu sonuç istatistiksel olarak anlamsızd. Trizomi $56(\%$ 96.56) hastada en s1k görülen kromozomal anormallik iken olgulardan sadece 2 (\% 3.45) mozaikti. Translokasyon tespit edilmedi. Tüm hipotiroidizm vakaları Trizomi 21'in sayısal kromozomal anomalisidir.

Sonuç: Subklinik hipotiroidi, Down sendromlu hastalarda görülen ve tüm yaş gruplarında anlamlı farklılık göstermeyen en yaygın tiroid fonksiyon bozukluğuydu.

Anahtar Kelimeler: Down sendromu, kromozomal anormallikler, tiroid fonksiyonu

\section{ABSTRACT}

Objective: Autoimmune diseases are known to occur in people with Down syndrome, especially the hypothyroidism. The main objectives of the present study were to estimate the frequency of abnormal thyroid function in Down syndrome patients and to assess their relation to the age, craniofacial features and the type of chromosomal abnormalities in Duhok province, Iraq.

Materials and Methods: The study included fifty eight patients with Down syndrome; all of them were examined for the presence of the main craniofacial features. Blood samples were collected from them to perform the thyroid function test and the karyotyping for chromosomal analysis.

Results: Out of 58 patients with Down syndrome, 25 (43.11\%) had subclinical hypothyroidism. There was no statistical significance between age group and percentage of subclinical hypothyroidism. The most frequent craniofacial feature was the epicanthal folds with a relatively high percentage of subclinical hypothyroidism, but this result was statistically insignificant. Trisomy was the commonest chromosomal abnormality seen in 56(96.56\%) patients and only $2(3.45 \%)$ were mosaic. No translocation was detected. All the cases of hypothyroidism were numerical chromosomal abnormality of Trisomy 21 .

Conclusions: The subclinical hypothyroidism was the commonest thyroid dysfunction seen in Down syndrome patients with no significant differences in all age groups. Keywords: Chromosomal abnormalities, Down syndrome, thyroid function

Yayın Bilgisi / Article Info:

Gönderi Tarihi/ Received: 22/12/2019

Kabul Tarihi/ Accepted: 06/02/2020

Online Yayın Tarihi/ Published: 30/06/2020
Dian Jamel Salih
Swaro 151, Duhok/ Iraq

Telephone: 009647504568201

E-mail address: dian.jamel@uod.ac 


\section{INTRODUCTION}

Down syndrome (DS) is one of the most common chromosomal aneuploidy and the best known of all malformation syndromes, with an estimated prevalence of 1 per 650-1000 births worldwide. The incidence of DS in Duhok province of Iraq is 11960 , which is within the world average. ${ }^{1,2}$

Down syndrome is associated with mental retardation, metabolic and endocrine disorders, several congenital anomalies, including cardiovascular and gastrointestinal systems. The most frequent endocrine disorders associated with DS are thyroid related disorders. ${ }^{3}$ Different autoimmune conditions may affect DS patients, especially the hypothyroidism that might appear at birth or later in life. It has been found that congenital hypothyroidism may affect DS patients 28 times more than the general population. ${ }^{4}$ In general, the signs and symptoms of hypothyroidism include dry and rough skin, tiredness, intolerance, constipation, drowsiness, apathy, motor clumsiness, weight gain, change in voice tone, and macroglossia. Most of these signs are frequent in individuals with DS. ${ }^{5}$

Alterations of thyroid function frequently occur throughout the life of DS patients. If these dysfunction left untreated may affect the development and quality of life. Therefore, accurate diagnosis is an essential step to treat this dysfunction. It is reported that $1 \%$ of people with DS might develop hypothyroidism at birth, but this percentage increase with age, therefore, it is recommended to assess the thyroid stimulating hormone (TSH) annually. ${ }^{6}$

The early detection of DS is an essential step to maximize cognitive abilities in this already impaired population. The health supervision guidelines for children with DS suggested reviewing results of the newborn thyroid function screen, then repeating thyroid function tests annually.

The elevated TSH, normal triiodothyronine $\left(\mathrm{T}_{3}\right)$ and thyroxine $\left(\mathrm{T}_{4}\right)$ levels is defined as subclinical hypothyroidism. Previous studies reported that the subclinical hypothyroidism is the most common thyroid condition in this syndrome, and since the hypothyroidism or thyroid dysfunction can be congenital or acquired in patients with DS, therefore, these patients should be followed up periodically test for thyroid functions since birth. ${ }^{8,9}$

The present study aims to determine the frequency of thyroid dysfunction and hypothyroidism in patients with DS and their correlation with the patient's age, and other clinical features, including the craniofacial features of DS, that might differ according to the severity of the disease, and with the type of chromosomal abnormalities in the affected patients in Duhok province, Iraq.

\section{MATERIALS AND METHODS}

Sample collection and ethics Statement: This is a cross-sectional descriptive study, which included 58 DS patients from Duhok province. The study was conducted from April 2019 to September 2019 and the ethical approval (Date: 06.02.2019 and Decision no: 79) was obtained from the college of medicine research ethics committee, and permissions from all children parents have been taken.

Patients were examined and filled a list of the craniofacial feature, which included: Up-slanting palpebral fissures, epicanthic folds, open small mouth, protruding tongue, depressed nasal bridge, high arched palate, furrowed tongue, flat facial features, low set, small ears, flat occiput (Brachycephaly), Hypertelorism (increase in the inter-orbital distance), open fontanel, short neck, excessive skin folds on neck and microcephaly.

Blood samples were collected from patients for chromosomal study and the assessment of the thyroid function by estimating the TSH, free $\mathrm{T}_{4}$ and $\mathrm{T}_{3}$ levels. The cytogenetic analyses and karyotyping were performed at the college of medicine, university of Duhok.

The thyroid function test was carried out by obtaining $500 \mu \mathrm{l}$ of serum sample from patients, then measure the levels of TSH, $\mathrm{T}_{3}$ and $\mathrm{T}_{4}$ by MAGLUMI 1000 Chemiluminescence immunoassay (CLIA). The following standard normal ranges were depended: TSH: $0.3-4.5 \mathrm{uIU} / \mathrm{ml}, \mathrm{T}_{3}: 0.69-2.15$ $\mathrm{ng} / \mathrm{ml}$ and $\mathrm{T}_{4} 52-127 \mathrm{ng} / \mathrm{ml}$. The Types of thyroid dysfunction were categorized into hypothyroidism, subclinical hypothyroid and hyperthyroid status according to the criteria shown in Table 1.

Karyotype analysis: The chromosomal analysis was carried out by adding $0.5 \mathrm{ml}$ of peripheral blood to a culture tube containing $10 \mathrm{ml}$ of culture solution (RPMI 1640 with L-glutamine, Phytohemaglutinin, Fetal bovine serum, Penicillin-Streptomycin) and incubated for 72 hours at $37^{\circ} \mathrm{C}$, and then $200 \mu 1$ of Colcemid were added. After 1 hour, mixture were treated with hypotonic solution (KCL 0.25 in $50 \mathrm{ml}$ distilled water) and fixation solution (Methanol: Glacial acetic acid 3:1), and then slides prepared and stained with Geimsa stain to detect chromosomal abnormalities. 
Statistical analysis: Data analysis was performed by using IBM SPSS Statistics software version 22. Descriptive data were presented for continuous variables as mean $\pm \mathrm{SD}$, while qualitative data description done by calculating numbers and percentages. $\mathrm{T}$ -test was used to compare between two means and Chi-square (x2) tests used to compare between proportions, The $P$ value $\leq 0.05$ considered statistically significant.

\section{RESULTS}

Demographic study: The present study performed on patients who were clinically diagnosed as DS. The age of the participants patients ranged from 6 to 18 years with a median age of 11 years (mean $11.32 \pm 7$ years). Out of the 58 cases, 31 (53.44\%) were males and $27(46.56 \%)$ were females with male to female ratio of $1.14: 1$.

Out of the 58 patients, $33(56.89 \%)$ had normal thyroid function values, while $25(43.11 \%)$ patients had subclinical hypothyroidism. The distribution of these 25 patients by the age groups is seen in Figure 1 . Although a large number of the studied group (32 cases) was within the age group of 10-15 years, the subclinical hypothyroidism was distributed on all age group as follow: $28 \%, 60 \%$ and $12 \%$ for the patients less than 10 years, between 10-15 years and more than 15 years respectively. No statistical difference was seen between the distribution of these three age groups and the presence of subclinical hypothyroidism.

The most frequent craniofacial feature in this study was the epicanthal folds which present in 43 cases $(74.1 \%)$ in all age groups. A relatively high percentage of subclinical hypothyroidism was seen in these patients also but this result was statistically insignificant. The other three common features were; upslanting palpebral fissures, protruding tongue and depressed nasal bridge. The correlation of all craniofacial features with the age groups and the subclinical hypothyroidism in the patients with DS is presented in Table 2.

Cytogenetic and chromosomal analysis: The cytogenetic analysis for all patients with DS showed that the numerical abnormality of Trisomy 21 was the most common type of abnormality which detected in 56 cases $(96.5 \%)$, while only 2 cases $(3.5 \%)$ showed mosaicism and no chromosomal translocation was seen. All the cases of subclinical hypothyroidism (25 cases) found to be of numerical chromosomal abnormality of Trisomy 21, while the two cases of mosaic chromosomal abnormality where of normal thyroid function test.

The types and percentages of chromosomal abnormalities detected in all cases are shown in Table 3.

\section{DISCUSSION AND CONCLUSION}

The incidence of Down syndrome in Duhok province of Iraq is approximately $1 / 960$ live births, which is within most international ranges, especially with countries in the region like Turkey (1/1000 live births) and Iran (1/900 live births). ${ }^{1,10,11}$ The present study showed a relatively high incidence of subclinical hypothyroidism in patient with DS in Duhok province (43.11\%). In fact, the diagnosis and treatment of hypothyroidism in patients with DS are mostly depending on the clinical symptoms and the results of blood tests of TSH which is produced by the pituitary gland at the base of the brain. The high level of TSH and low level of thyroxin consider as a significant indicater to hypothyroidism condition. Increase the production of TSH stimulating thyroid gland to produce more thyroid hormone. ${ }^{12}$ Therefore the American Academy of Pediatrics recommended thyroid hormone testing for DS infants at birth and at 6 and 12 months of age. Even adult patients with DS must check their TSH level regularly, this will help health care professional in managing hypothyroidism since it helps them to determine the right dosage of medication, both initially and long term dose. $^{13}$

Thyroid hormones have a vital role for the development of the central nervous system during childhood, especially in the migration and differentiation of neuron and activation of the sympathetic nervous system. When hypothyroidism left untreated, may aggravate several complications correlated with DS during infancy and childhood, such as psychomotor development, somatic growth and mental retardation. $^{14}$

The association between DS and thyroid dysfunction is well recognized. Previous works were investigated the association between DS and thyroid dysfunction, for instance, ; some authors reported that neonates suffer from hypothyroidism 28-times more than the normal newborns. ${ }^{15}$ Gibson et al., (2005) conducted study focus on DS children on different ages and at two different time period. This study demonstrated that these abnormalities were decreased with age. ${ }^{16}$ However Predieri and his coworkers found that the normal thyroid function values in patients with DS were significantly decreasing over a period of 10-year follow-up. ${ }^{17}$

Unlike these two researches the current study found 
no significant differences among the patients; bellow 10 years, between $10-15$ and those over 15 years. It is difficult to compare these results with normal population who suffer from thyroid dysfunction since the data available of this disease in newborn are uncertain. Therefore, it is important to have registration of all patients with DS so that timely screening for hypothyroidism can be performed. ${ }^{15}$

On the other hand, Wassner and Brown found that there is increasing in incidence of hypothyroidism in newborns in general, and they stated that [Primarily due to increased stringency of screening strategies, with smaller contributions from changing demographics and improved survival of increasingly premature infants]. ${ }^{18}$

The commonest four craniofacial features in this study were the epicanthal folds, the up-slanting palpebral fissures, the protruding tongue and the depressed nasal bridge. However the karyotyping is important to confirm the diagnosis.

The current study showed that most DS patients had numerical abnormality of Trisomy 21 and all the cases of subclinical hypothyroidism were of this category. Unfortunately, the low number of mosaicism patients made the statistical analysis between patients with normal thyroid function values and those with the subclinical hypothyroidism insignificant. Further studies with larger number of DS patients need to be performed to get representative results.

In conclusion; the present study concluded that Thyroid dysfunction, which represented by the subclinical hypothyroidism, is common in children with DS and distributes in all age groups with no significant differences. Consequently, this study recommended annual screening for SD patients as a prophylactic step.

Ethics: This study started after the approval of the Duhok medical scientific and ethical committee (Date: 06.02.2019 and decision no: 79)

Conflict of Interest: No conflict of interest was declared by the authors.

Author Contributions: Concept-DS; SupervisionMY; Materials-RM; Data Collection and/or Processing-DF; Analysis and/ or Interpretation - DS, MY; Writing-DS.

Peer-review: Externally peer-reviewed

\section{REFERENCES}

1. Salih D, Bakir N, Adil E, Al-Allawi N. Clinical and Cytogenetic Profile in Patients with Down
Syndrome in Duhok Province, Iraq. Medical Journal of Babylon. 2017;14(2):389-401.

2. Keppler-Noreuil K, Welch J, Major H, Qiau Q, Jordan D, Patil S. Atypical Down syndrome phenotype with severe developmental delay, hypertonia, and seizures in a child with translocation trisomy 21. Dev Med Child Neurol. 2002;44 (1):64-67.

3. Purdy B, Singh N, Brown W, Vangala S, Devaskar U. Revisiting early hypothyroidism screening in infants with Down syndrome. J Perinatol. 2014;34(12):936-940.

4. Davidson M. Primary care for children and adolescents with Down's syndrome. Pediatric Clinics of North America. 2008;55:1099-1111.

5. Kawther T, El-Shafie K. Clinical presentation of Hypothyroidism. J Family Community Med. 2003;10(1):55-58.

6. Marilyn J. Clinical report-health supervision for children with Down syndrome. Pediatrics. 2011;128(2):383-406.

7. Cunniff C, Frias J, Kaye C, Moeschler J, Panny S, Trotter T. American Academy of Pediatrics, Committee on Genetics Health supervision for children with Down syndrome. Pediatrics. 2001;107:442-450.

8. Henry E, Walker D, Wiedmeier S. Hematological abnormalities during the first week of life among neonates with Down syndrome: data from a multihospital healthcare system. American Journal of Medical Genetic. 2007;143:42-50.

9. Tonacchera M, Perri A, De Marco G. TSH receptor and GS (alpha) genetic analysis in children with Down's syndrome and subclinical hypothyroidism. J Endocrinol Invest. 2003;26:997-1000.

10. Acikbas I, Tomatir A, Akdag B, Koksal A. Sixteen years live-birth prevalence of children with Down syndrome in Denizli, Turkey. Genetics and Molecular Research. 2002;11(4):4640-4645.

11.Zahed Y, Vahedi A, Zamani M, Alizadeh-Navaei R, Zahed E. Prevalence of Birth Defects in Iran: A Systematic Review and Meta-Analysis. Arch Iran Med. 2017;20(6):376-385.

12.Fergeson M, Mulvihill J, Schaefer G, DeHaai K, Piat J, Combs K. Low adherence to national guidelines for thyroid screening in Down syndrome. Genetics in Medicine. 2009;11(7):548551

13. Bull M. Health supervision for children with Down syndrome. Pediatrics. 2011;128(2):393406. 
14. Oliveira A, Longui C, Calliari E, Ferone A, Kawaguti F, Monte O. Evaluation of the hypothalamic-pituitary-thyroid axis in children with Down syndrome. J Pediatr. 2002;78(4):295-300.

15. Cebeci A, Güven A, Yıldız M. Profile of Hypothyroidism in Down's syndrome. J Clin Res Pediatr Endocrinol. 2013;5(2):116-120.

16. Gibson P, Newton R, Selby K, Price D, Leyland $\mathrm{K}$, Addison $\mathrm{G}$. Longitudinal study of thyroid function in Down's syndrome in the first two decades. Arch Dis Child. 2005;90:574-578.

17. Predieri B, Garavelli L, Bonetti A, Vellani G, Predieri F,Cattelani C. Hypothyroidism in the Newborn Period, NCBR. 2013;20(5):449-454

18. Al-Shawaf R, Al-Faleh W. Craniofacial characteristics in Saudi Down's syndrome. King Saud University Journal of Dental Sciences. 2011;2:17 -22 . 
Table 1. Types of thyroid dysfunction.

\begin{tabular}{|l|l|}
\hline Thyroid dysfunction & \multicolumn{1}{c|}{ Description } \\
\hline Over hypothyroidism & Elevated TSH along with reduction in $\mathrm{T}_{3}$ and $\mathrm{T}_{4}$ indicates \\
\hline Subclinical hypothyroidism & $\begin{array}{l}\text { The serum level of TSH from the front of the pituitary gland is a little } \\
\text { bit above normal while the thyroid hormones produced by the thyroid } \\
\text { gland are still within the laboratory's normal range }\end{array}$ \\
\hline Hyperthyroidism & Elevated $\mathrm{T}_{3}$ and $\mathrm{T}_{4}$ indicate \\
\hline
\end{tabular}




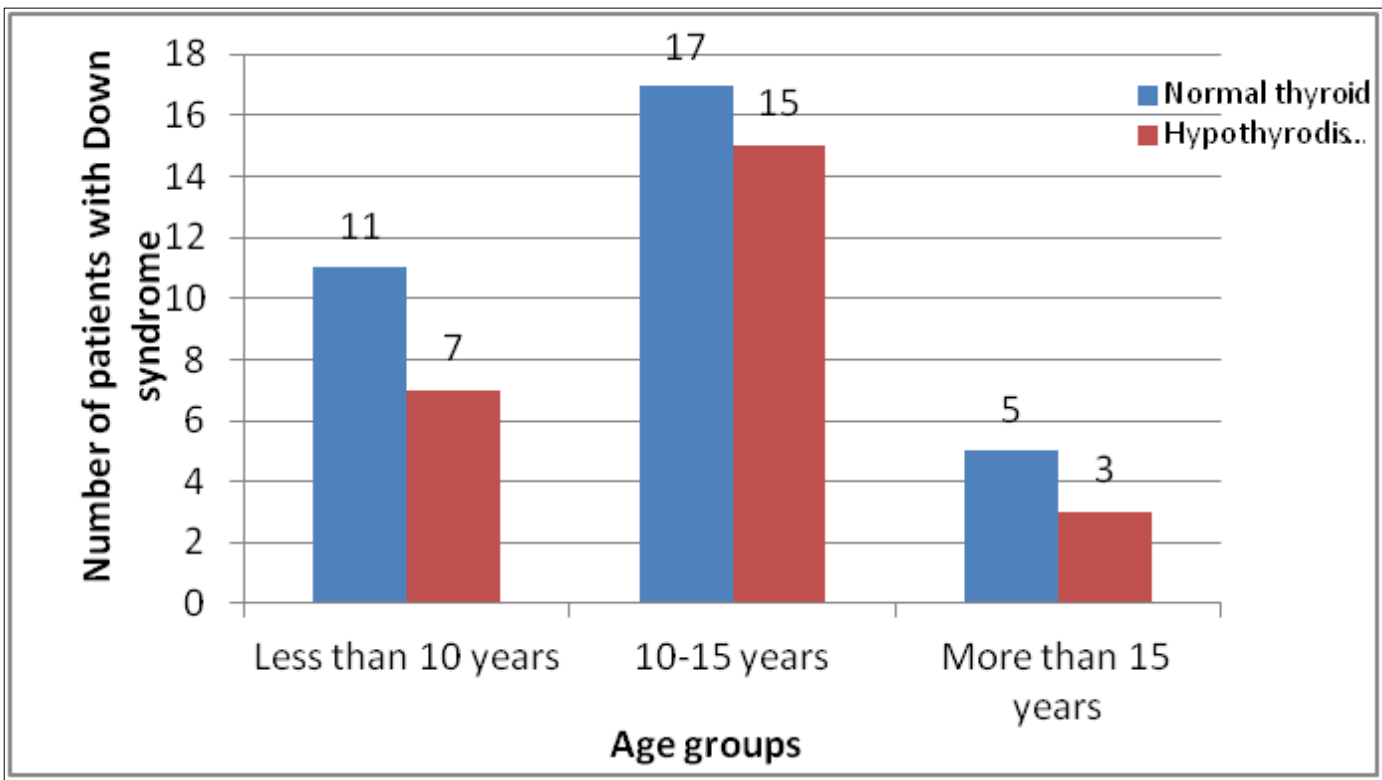

Figure 1 The correlation between the age groups and the subclinical hypothyroidism in patient with Down syndrome. 
Table 2. The correlation between the craniofacial features and the subclinical hypothyroidism in patient with Down syndrome.

\begin{tabular}{|c|c|c|c|c|c|}
\hline \multirow{3}{*}{ Craniofacial features } & \multicolumn{4}{|c|}{ Age groups } & \multirow{3}{*}{$\begin{array}{c}\begin{array}{c}\text { Thyroid func- } \\
\text { tion status }\end{array} \\
\begin{array}{c}\text { Subclinical } \\
\text { hypothyroidism }\end{array}\end{array}$} \\
\hline & $\begin{array}{l}\text { Less than } \\
10 \text { years }\end{array}$ & $10-15$ year & $\begin{array}{c}\text { More than } \\
15 \text { years }\end{array}$ & \multirow[t]{2}{*}{ Total } & \\
\hline & (18 cases) & (32 cases) & (8 cases) & & \\
\hline Epicanthal folds & 13 & 23 & 7 & $43(74.1 \%)$ & $17(29.3 \%)$ \\
\hline $\begin{array}{l}\text { Up-slanting Palpebral fis- } \\
\text { sures }\end{array}$ & 11 & 22 & 4 & $37(63.8 \%)$ & $15(25.9 \%)$ \\
\hline Protruding tongue & 11 & 17 & 7 & $35(60.3 \%)$ & $17(29.3 \%)$ \\
\hline Depressed nasal bridge & 9 & 20 & 6 & $35(60.3 \%)$ & $16(27.6 \%)$ \\
\hline Low set, small ears & 9 & 18 & 4 & $31(53.5 \%)$ & $16(27.6 \%)$ \\
\hline Flat facial features & 12 & 15 & 4 & $31(53.5 \%)$ & $10(17.2 \%)$ \\
\hline Short neck & 10 & 15 & 3 & $28(48.9 \%)$ & $12(20.7 \%)$ \\
\hline Brachycephaly & 10 & 13 & 3 & $26(44.8 \%)$ & $13(22.4 \%)$ \\
\hline Hypertelorism & 8 & 13 & 4 & $25(43.1 \%)$ & $11(19.0 \%)$ \\
\hline Microcephaly & 10 & 12 & 2 & $24(41.4 \%)$ & $12(20.7 \%)$ \\
\hline Furrowed tongue & 8 & 14 & 2 & $24(41.9 \%)$ & $10(17.2 \%)$ \\
\hline Open fontanel & 6 & 6 & 3 & $15(25.9 \%)$ & $7(12.1 \%)$ \\
\hline High arched palate & 2 & 12 & 1 & $15(25.9 \%)$ & $8(13.8 \%)$ \\
\hline Excessive skin folds on neck & 7 & 7 & 1 & $15(25.9 \%)$ & $7(12.1 \%)$ \\
\hline
\end{tabular}


Table 3. The frequency and percentages of chromosomal abnormalities.

\begin{tabular}{|l|c|c|c|}
\hline \multirow{2}{*}{ Chromosomal abnormality } & Karyotype & Frequency & \% \\
\hline \multirow{2}{*}{ Trisomy 21 } & {$[47, \mathrm{XY},+21]$} & 31 & $(53.44 \%)$ \\
\cline { 2 - 4 } & {$[47, \mathrm{XX},+21]$} & 25 & $(43.11 \%)$ \\
\hline Mosaic & {$[46, \mathrm{XX} / 47, \mathrm{XX},+21]$} & 2 & $(3.45 \%)$ \\
\hline Translocation & Not found & 0 & $(0.0 \%)$ \\
\hline
\end{tabular}

